\title{
Microvascular Density
}

National Cancer Institute

\section{Source}

National Cancer Institute. Microvascular Density. NCI Thesaurus. Code C96517.

The density of newly formed blood vessels in a tissue. Microvascular density can be used to describe the proliferation speed of a tissue, with higher density indicating faster tissue growth. 